\title{
TEORI GUDANG DIGUNAKAN DALAM PROSES PERGUDANGAN (TINJAUAN EMPAT ASPEK)
}

\author{
*Farhan Fadhilah ${ }^{1}$, Ryan Firdiansyah Suryawan ${ }^{2}$, Lilik Suryaningsih ${ }^{3}$, Lilis Lestari ${ }^{4}$ \\ 1,2,3 Sekolah Tinggi Penerbangan Aviasi, Jakarta Barat, DKI, Jakarta \\ ${ }^{4}$ Sekolah Tinggi Kesenian Wilwatikta, Surabaya,Indonesia \\ *Email Korespondensi: \\ ryan.firdiansyah.1979@gmail.com
}

\section{ARTIKEL INFORMASI}

Diterima:

25 Desember 2021

Direvisi:

12 Januari 2022

Dipublikasi:

30 Januari 2022

\begin{abstract}
ABSTRAK
Tujuan dari penelitian adalah untuk mengetahui gambaran manajemen pergudangan yang ada di perusahaan pergudangan dikaitkan dengan empat aspek sarana prasarana, tenaga kerja, prosedur kerja dan pelaksanaan kegiatan. Penelitian ini menggunakan metode penelitian kualitatif dengan melakukan survey untuk menggambarkan, menjelaskan, dan menginterpretasikan suatu fenomena yang terjadi pada suatu objek. FIFO dan FEFO dikaitkan dengan empat aspek yaitu sarana dan prasarana, tenaga kerja, standar operasional prosedur dan pelaksanaan kegiatan. Sarana dan prasarana dalam pelaksanaan pengoprasian Gudang terdapat kendala pada sarana yaitu pallet yang digunakan seringkali ditemukan rusak, akibatnya jumlah yang rusak menumpuk di area Gudang. Tenaga kerja di i sudah cukup dengan 10 orang dan melalui training pra kerja maka staf dapat berkomunikasi dengan baik, bekerja sesuai prosedur yang berlaku, dapat memecahkan masalah dan dapat bekerja secara professional. Prosedur kerja, yang diterapkan di perusahaan sudah memenuhi kriteria, Hal ini juga menjadi patokan atau tolak ukur staf untuk mengambil langkah-langkah yang tepat dalam kegiatan kerja serta Pelaksanaan kegiatan, Pelaksanaan kegiatan sudah berjalan dengan baik, karena ada jaminan 100\% akurasi dalam setiap aktivitas di dalam gudang.
\end{abstract}

Kata Kunci: Proses Gudang, FIFO, FEFO

\section{PENDAHULUAN}

Peran Manajemen Operasi Pergudangan harus dapat mengatur dengan maksimal agar barang-barang yang disimpan di tempat penyimpanan atau warehouse dapat disimpan sesuai dengan jenis, ukuran, berat, dan sifat barang tersebut. Hal ini diperlukan agar barang barang yang berbeda jenis di dalam satu gudang tidak terganggu. Dan pada saat akan dilaksanakannya delivery barang- barang tersebut dapat dikeluarkan dengan efektif dan efisien, begitu juga sebaliknya dengan receiving. Sarana dan prasarana agar dapat mempermudah petugas gudang dalam menangani suatu barang yang akan disimpan dan memeriksa barang dengan teliti dan benar. pesatnya perkembangan teknologi telah membuat persaingan di dunia usaha menjadi semakin meningkat dan menuntut perusahaan untuk terus melakukan perbaikan efisiensi operasi mereka dengan tujuan mencapai profitabilitas 
yang tinggi. Oleh karena itu, sistem FIFO (First In First Out) dan FEFO (First Expiry First Out) penting untuk memberikan kepastian dalam pencapaian tujuan, yaitu efektivitas dan efisiensi operasi.

Aspek sarana dan prasarana sangatlah penting untuk mengelola pergudangan dan pendistribusian Barangbarang agar barang yang tersimpan masih dalam keadaan baik. Tetapi pada saat pelaksanaan dilapangan ditemukan beberapa kekurangan yang dialami oleh petugas seperti rusaknya AC dan Pengukur suhu atau peralatan penunjang untuk pengukuran suhu yang disebabkan oleh kurangnya monitoring dan perawatan pada seluruh peralatan. Kekurangan yang terjadi pada kegiatan operasional terjadi karena didasari oleh beberapa faktor, seperti faktor alam, faktor petugas, faktor pengawasan dari supervisor, karena begitu pentingnya suhu untuk barang seperti Obat-obatan hewan, Suatu proses penyimpanan suatu barang tidak lepas dari tata cara dalam penyimpanan barang tersebut baik dari segi metode yang digunakan untuk mengangkat barang tersebut sampai cara pengangkutan barang tersebut sampai dengan cara penyusunan dan atau penyimpanan barang tersebut agar aman dan terjaga kualitasnya.

Pemetaan suhu ruang penyimpanan dilakukan Oleh Petugas gudang dalam proses validasi dan mapping temperatur. Termometer ditempatkan pada titik panas dan titik dingin serta di dekat pintu suatu ruang penyimpanan. Suhu harus diperiksa serta dimonitor tiga kali sehari dan dicatat pada kartu monitor suhu untuk menjaga semua bagian dari area penyimpanan tetap dalam suhu yang ditentukan, Infrastruktur yang harus diperhatikan dan memenuhi persyaratan diantaranya adalah bangunan/ruangan untuk gudang sebagai tempat penyimpanan barang, suhu dan kelembaban ruangan, serta material handling equipment. Apabila infrastruktur dan fasilitas tidak memadai, maka Petugas Penanggung Jawab Teknis Obat Hewan mengusulkan kepada Pimpinan untuk memenuhi kekurangannya. Sistematika penyusunan barang dalam penyimpanan disesuaikan dengan kebutuhan, misalnya barang yang memiliki masa kadaluarsa (sudah masuk masa ED) dikumpulkan tersendiri dan diberi tanda-tanda yang jelas agar selalu dapat dimonitor. Barang yang fast moving ditempatkan di bagian yang mudah dijangkau dan sebagainya.

\section{KAJIAN PUSTAKA}

Menurut Kuswoyo (2015) Gudang adalah suatu fungsi penyimpanan macam jenis produk yang memiliki unit penyimpanan dalam jumlah maupun kecil dalam jangka waktu saat produk dihasilkan oleh pabrik dan saat produk dibutuhkan oleh pelanggan atau stasiun kerja dalam fasilitas produksi. Gudang sebagai tempat yang dibebani tugas untuk menyimpan barang yang akan digunakan dalam produksi, sampai barang tersebut diminta sesuai dengan jadwal produksi. Dalam sistem pergudangan yang baik adalah sistem yang mampu memanfaatkan ruang untuk penyimpanan secara efektif agar dapat meningkatkan ruang penyimpanan yang kurang efektif yang mengakibatkan banyaknya produk yang tidak tertampung dalam Gudang. Menurut Meyers, (2015:154). Gudang adalah suatu area terpisah yang digunakan untuk menyimpan bahan baku, part dan juga persediaan. Gudang yang baik bukanlah gudang yang memiliki area yang sangat besar. Gudang dengan area yang terbatas pun dapat memiliki kapasitas maksimal jika ditunjang dengan tata letak yang baik. Hal yang perlu diperhatikan dalam tata letak gudang adalah 2 efektivitas dan efisiensi proses pemasukan dan pengeluaran barang. Efektivitas dan efisiensi proses pemasukkan dan pengeluaran ini akan dapat dicapai misalnya dengan menyusun barang agar tempat yang ada dapat dimanfaatkan secara optimal. Gudang adalah fasilitas untuk yang bertujuan untuk menyimpan barang sebagai penyangga permintaan sehingga permintaan yang terjadi dapat dipenuhi. Selain itu, gudang juga berfungsi menjadi titik pengiriman barang dimana semua, barang diterima dan dikirim secepat, seefektif dan seefisien mungkin. (Richard, 2014).

Tujuan dari adanya tempat penyimpanan dan fungsi dari pergudangan secara umum adalah:

a. Kebutuhan Produksi Gudang dibuat untuk menunjang kebutuhan produksi, dimana dalam proses produksi biasanya barang yang dihasilkan memiliki sifat yang berbeda sehingga dapat dikelompokkan berdasarkan barang yang bisa langsung dikonsumsi dan barang yang terlebih dahulu disimpan.

b. Pengurangan biaya transportasi dan produksi Fasilitas gudang juga bertujuan untuk mengurangi biaya transportasi dan produksi, dikarenakan dengan adanya peran dari gudang tersebut sebagai penyimpanan barang persedian produksi.

c. Pengkoordinasian antara penawaran dengan permintaan. Permintaan pasar tidak selalu bisa dipastikan dengan akurat sedangkan penawaran harus terus berjalan, sehingga dengan adanya gudang bisa 
mengkoordinasikan antara penawaran dengan permintaan. Sehingga gudang dapat menyimpan barang saat jumlah produksi naik dan permintaan menurun.

d. Kebutuhan Pasar Agar pemasokan barang tidak terputus maka diperlukannya gudang untuk menyimpan persediaan barang, sehingga dapat memenuhi permintaan barang yang harus selalu ada oleh konsumen.

Jenis gudang Berdasarkan jenis barangnya, terdapat beberapa tipe gudang, yaitu:

1. Gudang bahan baku

Gudang ini digunakan sebagai tempat untuk menyimpan bahan baku pada proses produksi telah selesai.

Lokasi gudangnya tidak akan jauh dari tempat produksi karena memang selesai produksi, barang-barang tersebut akan dibawa ke gedung penyimpanan bahan baku. Beberapa bahan baku yang biasanya disimpan di sini antara lain: biji besi, karet, material beton, dan lain sebagainya.

2. Gudang Sebagai Tempat Penyimpanan Barang Jadi

Gudang yang digunakan untuk menyimpan barang-barang hasil produksi. Barang-barang yang sudah siap didistribusikan akan terlebih dahulu disimpan di gedung ini. Kemudian barang-barang tersebut akan dikirimkan berdasarkan kebutuhan konsumen.

3. Gudang Sebagai Pusat Konsolidasi Serta Transit

Gudang yang satu ini memiliki fungsi sebagai tempat untuk transit serta konsolidasi. Barang-barang yang diperoleh dari pusat kemudian akan digabungkan terlebih dahulu. Selanjutnya barang tersebut akan diteruskan untuk diberikan kepada para konsumen.

4. Gudang Sebagai Transhipment

Gudang ini dipakai sebagai tempat penyimpanan berbagai macam barang yang berukuran besar. Setelah barang tersebut selesai dilakukan pembagian atau proses sortir dengan membaginya ke jumlah yang lebih kecil, maka barang tersebut sudah siap dikirim ke konsumen.

Menurut Miranda (2011:107) Manfaat gudang dalam logistik dapat dilihat dari dua sudut pandang yaitu dari segi ekonomi dan pelayanan:

1. Manfaat ekonomi Manfaat gudang dari segi ekonomi yaitu apabila keseluruhan biaya logistik mengalami penurunan dengan adanya

pemanfaatan satu atau beberapa fasilitas gudang

2. Manfaat pelayanan Manfaat pelayanan yang diperoleh dengan pemanfaatan yang diperoleh dengan pemanfaatan gudang dalam logistik mungkin tidak dapat mengurangi biaya, namun dapat memperbaiki pelayanan dengan mengurangi waktu pengiriman dan kapabilitas tempat.

\section{METODE}

Metode penelitian yang digunakan adalah kualitatif dengan dengan melakukan survei untuk menggambarkan, menjelaskan, dan menginterpretasikan suatu fenomena yang terjadi pada suatu objek yang dikaitkan dengan empat aspek yaitu sarana prasarana, tenaga kerja, prosedur kerja, dan pelaksanaan kegiatan.

\section{HASIL DAN PEMBAHASAN}

Adapun hasil pembahasan dilihat dari empat aspek hasil dari observasi lapangan, wawancara dengan karyawan perusahaan penerbangan didapatkan hasil sebagai berikut ;

a. Sarana dan Prasana mendapatkan jawaban Infrastruktur yang harus diperhatikan dan memenuhi persyaratan diantaranya adalah bangunan/ruangan untuk gudang sebagai tempat penyimpanan barang, suhu dan kelembaban ruangan, serta material handling equipment.

b. Tenaga Kerja, sesuai hasil pengamaatan atau observasi bahwa evaluasi perusahaan adalah kesediaan helm (safety) untuk seluruh karyawan gudang demi tercapainya K3 (Keselamatan, Kesehatan, Kerja)

c. Prosedur kerja, prosedur kerja yang berisi langkah- langkah proses inbound sampai ke outbound harus diikuti sesuai SOP yang berlaku di gudang yaitu, safety terhadap penanganan barang maupun terhadap pekerja itu sendiri, sehingga dengan prosedur kerja yang sudah diterapkan seluruh tujuan perusahaan dapat tercapai

d. Kegiatan pertama yang dilakukan pada gudang adalah receiving, yaitu kegiatan di mana barang yang telah dikirimkan oleh customer sampai pada bagian operasional, dan akan dilakukan pengecekan terhadap barang, sehingga barang akan di-scan untuk masuk ke dalam gudang. Hal ini terjadi dengan cara scanning barang 
melalui pallet id-nya. Kegiatan selanjutnya adalah value add, dimana dilakukan ketika barang telah diterima di dalam gudang. Hal yang dilakukan ini adalah dengan memasukkan data barang yang diterima ke dalam sistem yang ada. Kegiatan selanjutnya adalah put away, yaitu ketika semua barang yang sudah diterima akan dipindahkan ke beberapa lokasi yang berbeda. Ada dua cara yang dilakukan dalam hal ini, yaitu discan langsung atau secara manual. Sistem akan menyimpan data lokasi berdasarkan di daerah mana barang itu diterima. Hal ini dilakukan oleh bagian operasional. Hal selanjutnya yang dilakukan pada inbound adalah inventory management. Hal ini dilakukan ketika barang di dalam gudang akan dikontrol oleh bagian admin dan manajer. Hal ini akan dilakukan berdasarkan unit id. Semua transaksi yang ada dalam gudang akan disimpan secara real time.

\section{KESIMPULAN DAN SARAN}

Sarana dan prasarana, dalam pelaksanaan pengoprasian Gudang terdapat kendala pada sarana yaitu pallet yang digunakan seringkali ditemukan rusak, akibatnya jumlah yang rusak menumpuk di area Gudang. Tenaga kerja di PT. Akusara Indonesia Abadi sudah cukup dengan 10 orang dan melalui training pra kerja maka staf dapat berkomunikasi dengan baik, bekerja sesuai prosedur yang berlaku, dapat memecahkan masalah dan dapat bekerja secara professional, Prosedur kerja yang diterapkan sudah memenuhi kriteria, Hal ini juga menjadi patokan atau tolak ukur staf untuk mengambil langkahlangkah yang tepat dalam kegiatan kerja, Pelaksanaan kegiatan sudah berjalan dengan baik, karena ada jaminan 100\% akurasi dalam setiap aktivitas di dalam Gudang

\section{Daftar Pustaka}

Ahmad Sopian | May 13, 2020 https://jendela360.com/info/jenis-gudang/

Elqorni Ahmad, 2009. Perngertian Sistem Manajemen Pergudangan.

https://elqorni.wordpress.com/2009/11/11/sistem-manajemen-gudang/

Gayuh Kurniawan ,2016 Diakses Pada Web

https://repository.unugha.ac.id/570/1/TATA LETAK FASILITAS PABRIK DEPARTEMEN GUDANG Di

PT.BOTON INDONESIA.pdf. Dicky Fahrizal 2019 di akses Pada Web :

http://repository.stei.ac.id/2386/6/COVER PENDAHULUAN

https://www.transcon-indonesia.com/id/blog/metode-fifo-fefo-lifo-dan-average

October 2019 https://www.3pl.co.id/manajemen-pergudangan-logistik/.

Oleh Muchlisin Riadi April 30, 2016 https://www.kajianpustaka.com/2016/04/pengertian- tujuan-dan-manfaatgudang.html

Penyimpanan-barang-di-gudang-dengan.html https://www.porosilmu.com/2016/11/

Rinda Faradilla , https://www.idntimes.com/business/economy/rinda-faradilla/apa-itu- gudang/6

Warman, John. (1971). Warehouse Manajemen. Jakarta : Lembaga Pendidikan dan Pembinaan Manajemen Pustaka Sinar Harapan. 